\title{
Determination of Calcium and Magnesium Content Following the Natural Brine Adding in Some Dairy Products
}

\author{
Rodica SOMEŞAN ${ }^{1}$, Ildikó BARABÁSI, Laurenț OGNEAN ${ }^{2 *}$ \\ ${ }^{1}$ Department of Physiology, University of Agricultural Science and Veterinary Medicine \\ Manastur street, no. 3-5, 400037, Cluj-Napoca, România \\ *Corresponding author: lognean@yahoo.com \\ Bulletin UASVM Veterinary Medicine 72(2) / 2015, \\ Print ISSN 1843-5270; Electronic ISSN 1843-5378 \\ DOI:10.15835/buasvmcn-vm: 11319
}

\begin{abstract}
Our study aimed to determine and quantify the calcium and magnesium addition given by natural brine used in the processing of two dairy products. The research has been made on brine samples (natural and conventional) and commercially processed dairy (telemea and cheese) in the south-west Oriental Carpathian Mountains. We determined the calcium and magnesium content of the studied milk by two comparative methods (Perkin Elmer ICP device and complexometeric method) together with other basic physical and chemical parameters: dry matter/ humidity (steamer drying method), fat (butirometric method), sodium chloride (Mohr method) and pH (with an electronic $\mathrm{pH}$ meter). We also investigated the preferences of two consumer groups through tastings, for salted/ unsalted cheese and cheese salted with natural/conventional brine. Data analysis revealed that calcium as well as magnesium content are significantly higher in Cheese $(\mathrm{p}=0.008)$ and natural brine $(\mathrm{p}=0.009)$ added in Telemea $(p=0.10)$. In the consumer preferences, results have shown a predominance for salted Cheese $(90.3 \%)$, followed by Cheese prepared in natural brine (69.2\%). We concluded that, natural, mineral rich brine resulted to be mostly relevant and can increase the biological and sensory qualities of dairy products for a lower processing price.
\end{abstract}

Keywords: brine, cheese, ICP, complexometrie, calcium, magnesium

\section{INTRODUCTION}

Milk and dairy products occupy an important role in the human diet, serving as a major source for nutritional and biological active elements. Predominant elements in their composition are the macronutrients (proteins, lipids, carbohydrates) alongside with micronutrients (minerals and vitamins) that represent a smaller but essential component for sustaining the body's vital functions (Vahčić et al., 2010).

The mineral fraction of milk is composed by macro elements $(\mathrm{Ca}, \mathrm{Mg}, \mathrm{Na}, \mathrm{K}, \mathrm{P}, \mathrm{Cl}$ ) and oligoelements $(\mathrm{Fe}, \mathrm{Cu}, \mathrm{Zn}, \mathrm{Se})$, distributed differently among the liquid and fatty phases of milk. The most part of calcium is found in the liquid phase, associated mostly (65\%) with casein. Calcium, magnesium and zinc concentration of milk is relatively constant, variation along the lactation pathway are insignificant (Haug et al., 2007).

Minerals are present in every category of milk and dairy product, their content being influenced by processing. Calcium content depends upon the acidifying stage of processing and the acidifying stage along with the evacuation step, determine a fall of calcium content in cheese. It is considered that calcium content rises along the following dairy products: milk, fermented milk, cottage cheese, soft cheese, semi hard cheese and hard cheese (Gaucheron, 2011).

Besides the assured nutritional and biological value, the consumers needs for sensorial satisfaction and safety have to be met as well, that depend mostly on biochemical processes 
and manufacturing technology. Their accuracy is mostly responsible for a superior final product in taste, aroma, texture and aspect (Ognean et al., 2012; Someşan et al., 2013).

Starting from these facts, milk processing in safe conditions has become a major preoccupation for today's society, due to the profound effects that food and diet have over the consumer's state of health. There is a tendency to promote sodium poor food due to the fact that there is evidence sustaining that a salty diet increases the risk for cardiovascular and renal disease (He and MacGregor, 2010, 2011). Moreover, it is demonstrated that a sodium poor diet is the most efficient measure to improve public health status (Asaria et al., 2007).

Due to these studies that prioritize consumer health, the dairy industry is confronting a major challenge as it is known that salt is of grave importance in forming the savor and product safety of cheese (Johnson et al., 2009). Small decreases (10 up to 25\%) of salt content in cheese are accepted by consumers (Lawrence et al., 2009), but a greater decrease in salt lowers consumer preferences (Ganesan and Brown, 2014). All these facts constitute basic arguments for maintaining essential characteristics and food safety of a certain product, in especially dairy.

The presented arguments justify the present study of evaluating and quantifying calcium and magnesium content and the influence of natural brine in the process of obtaining dairy products in a sub Carpathian mountain region.

\section{MATERIALS AND METHODS}

Between October 2014 and March 2015, two batches of processed dairy products have been taken into study (Cheese and Telemea) with two batches of brine (natural and conventional) collected from a processing plant in the southwest Oriental Carpathian Mountains. This plant processes milk obtained in conditions of the sub Carpathian mountain region, where indigenous cattle breeds are held in traditional and commercial farming conditions. The predominant breed in this area is Romanian Spotted breed and its mixes that, through a long lasting selection developed lines with a great capacity to adapt to the local conditions. These proved resistant to disease and well adapted to the climate and the mountain region. The feed of these cows consist mainly of grazing in the summer and dry feed (hay) from this region, during the winter, with the addition of concentrates (maize and hulls).

Research started by identifying cheese types and integrating them into product standards according to today's legislation requirements and those set by the processing plant. Therefore, based on the evaluations made, it has been set, that the two types of dairy, Cheese and Telemea are obtained using a traditional method, specific to the region taken into study. The particularity of this method is that it uses natural occurring brine as the region has a salt deposit.

The Cheese type taken into study has a 54\% DM (dry matter) content and is obtained from standardized raw milk with a fat/protein ratio of 0.96 and coagulated with chymosin. The process includes: maturation at a $\mathrm{pH}$ of 4.9-5.2, followed by slicing and boiling $\left(74-78^{\circ} \mathrm{C}\right)$ in a natural brine bath of $6-8 \%$, finally drained, packed and deposited at $2-8^{\circ} \mathrm{C}$.

The tested Telemea type contains 40\% DM and is obtained from standardized milk with a fat/protein ratio of 0.87 , pasteurized $\left(85^{\circ} \mathrm{C}\right.$ for 3 minutes) and coagulated with chymosin and added lactic acid and calcium chloride. The process includes: slicing the curd and maintaining it in natural brine of $14-16 \%$, for $7-14$ days, at $2-8^{\circ} \mathrm{C}$; draining, packing and depositing at $2-8^{\circ} \mathrm{C}$.

At this point we would like to mention, that to be able to quantify the impact of natural brine, we also used conventional brine for this study (made of water and salt) at the same concentration in $\mathrm{NaCl}$ as the natural one. Initially the salt concentration of the brine (natural and conventional) was 24\% that was later diluted with water according to the concentration used in the production process (6$8 \%$ and $14-16 \%$ respectively).

Every month two samples of every batch were collected to be analyzed in the laboratory. A total number of 48 tests have been made, 12 for every sample. These were tested for physical and chemical properties, calcium and magnesium quantification (with Perkin Elmer ICP device and complexonometry) along with other basic parameters: dry matter/humidity (steamer drying method), fat (butirometric method), sodium chlorine (Mohr method) and $\mathrm{pH}$ (with an electronic $\mathrm{pH}$-meter).

Research continued with tastings to inquire consumer preferences of two groups for the 
following types of cheese: salted cheese/unsalted cheese and cheese salted with natural brine/ cheese salted with conventional brine, respectively.

Obtained data has been statistically analyzed with GraphPad InStat $3 \quad(p=0.05$ representing a significant result) and Fisher test.

\section{RESULTS AND DISCUSSION}

Calcium and magnesium content revealed variations among the two types of dairy products and the two types of brine, linked to product type and inorganic component.

Calcium and magnesium evolution in types of dairy revealed a mean level of $855 \mathrm{mg} / 100 \mathrm{~g}$ of calcium in Cheese $605.8 \mathrm{mg} / 100 \mathrm{~g}$ in Telemea, the differences between the two types are statistically significant $(p=0.008)$. Comparative analysis of these values showed $294.2 \mathrm{mg}$ greater calcium content in Cheese as in Telemea (Fig. 1). As for mean magnesium values, results have showed a mean value of $40.02 \mathrm{mg} / 100 \mathrm{~g}$ for cheese and 64.3 $\mathrm{mg} / 100 \mathrm{~g}$ for Telemea (Fig. 2). By comparing these results, a higher magnesium level of $24.28 \mathrm{mg}$ in Telemea as compared to Cheese has been revealed, without any statistically significant correlation among the set values $(\mathrm{p}=0.10)$.

Calcium and magnesium evolution in types of brine indicated a mean calcium level of $529 \mathrm{mg} / \mathrm{L}$ in natural brine and $87.7 \mathrm{mg} / \mathrm{L}$ in conventional brine, the differences being statistically significant $(p=0.009)$. These results showed a $414.3 \mathrm{mg} / \mathrm{L}$ higher calcium level in natural brine as compared to the conventional type (Fig. 3). The results

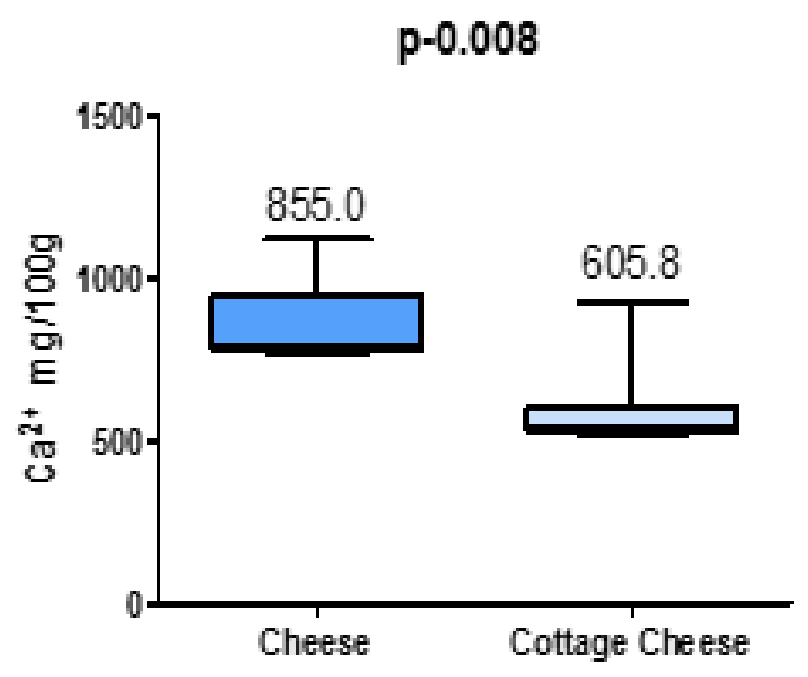

Fig.1. Mean values of calcium in types of dairy of this study revealed $59.7 \mathrm{mg} / \mathrm{L}$ magnesium content of magnesium in natural brine and 30.4 $\mathrm{mg} / \mathrm{L}$ in the conventional one (Fig. 4). As results indicated, natural brine contains $29.3 \mathrm{mg} / \mathrm{L}$ more magnesium than the conventional brine, the correlation between the values having a statistical significance $(\mathrm{p}=0.04)$.

$\mathrm{NaCl}$ and $\mathrm{pH}$ results showed a $\mathrm{NaCl}$ content of $24 \%(240 \mathrm{~g} / \mathrm{L})$ for both types of brine and a $\mathrm{pH}$ value of 6.59 in natural brine and 6.94 for conventional brine respectively.

The data obtained from the comparative determination of calcium levels in unsalted and salted (with natural brine) Cheese revealed some differences between the two types. Unsalted cheese has had a mean calcium content of 766 $\mathrm{mg} / 100 \mathrm{~g}$, whereas salted Cheese has had a mean calcium content of $780 \mathrm{mg} / 100 \mathrm{~g}$, with statistically significant differences $(\mathrm{p}=0.87)$. As for magnesium levels of the two types of cheese, results indicated a mean magnesium level of $25.8 \mathrm{mg} / \mathrm{L}$ for unsalted Cheese and $26.1 \mathrm{mg} / \mathrm{L}$ for salted cheese, with statistically insignificant differences $(p=0.73)$.

The data obtained from the comparative determination of calcium levels in unsalted and salted (with natural brine) Telemea revealed some differences between the two types. The unsalted type has had a mean calcium content 739 $\mathrm{mg} / 100 \mathrm{~g}$ and salted type a mean calcium content of $927 \mathrm{mg} / 100 \mathrm{~g}$, with statistically insignificant differences $(p=0.04)$. The mean magnesium content for the two types of Telemea showed 28.8 $\mathrm{mg} / \mathrm{L}$ in the unsalted and $43 \mathrm{mg} / \mathrm{L}$ in the salted

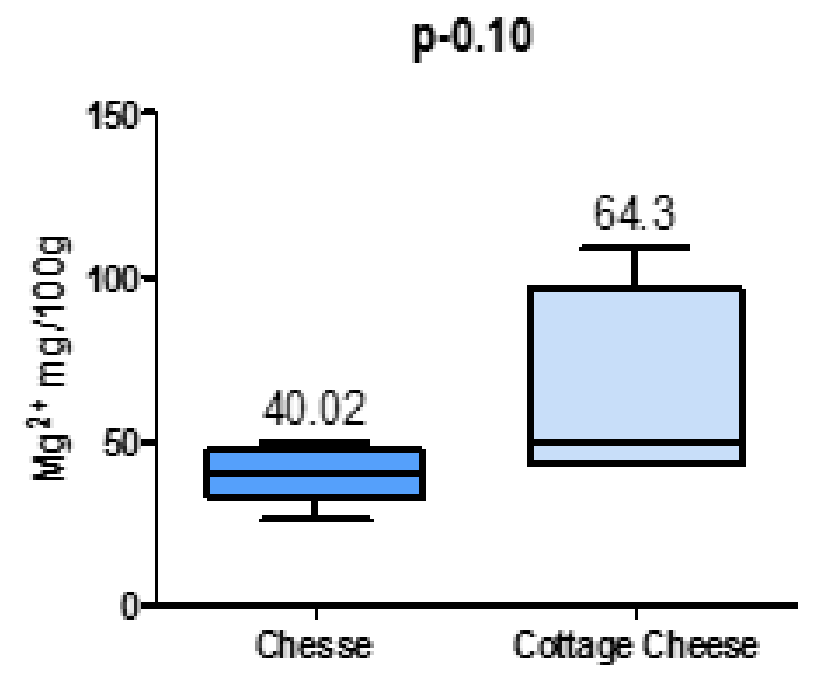

Fig.2. Mean values of magnesium in types of dairy 


\section{p-0.009}

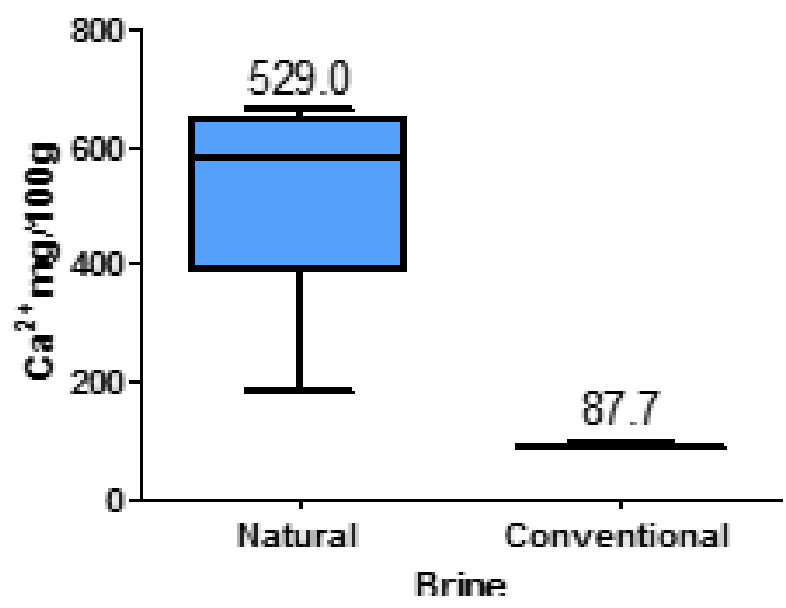

Fig.3. Mean values of calcium in brine

type, with statistically significant differences $(\mathrm{p}=0.0001)$.

Analyzing these results together, it is safe to confirm that calcium and magnesium rich natural brine brings an addition of these minerals to both types dairy products taken into this study. The most important addition of calcium (188 $\mathrm{mg} / 100 \mathrm{~g})$ magnesium $(14.2 \mathrm{mg} / 100 \mathrm{~g})$ has been made for Telemea. This is explained by the fact that in the case of Telemea a greater concentration (14$16 \%$ ) of natural brine has been used than in the case of Cheese (6-8\%). In addition to this, during the fabrication process of Telemea $2 \%$ of calcium chloride has been added, although new studies show that calcium chloride addition (10\%) does not result in statistically relevant modifications (McMahon et al., 2014).

According to the Institute of Medicine (1997) and Ross et al. (2011), recommended daily dose (RDD) for calcium is $700-1300 \mathrm{mg} /$ day and for magnesium $65-350 \mathrm{mg} /$ day. Viewed in this context, the results of the study showed that a daily intake of $100 \mathrm{~g}$ of Cheese or Telemea covers the calcium necessities of an adult for up to 60$70 \%$ and in $100 \%$ that for magnesium.

Mean salt content values reached $1.48 \%$ $(14.8 \mathrm{~g} / \mathrm{kg})$ for Cheese and $4.76 \%(47.6 \mathrm{~g} / \mathrm{kg})$ for Telemea. These results show that salt content is sufficient (Telemea), even though there have been some difference between dairy types, but this kind of results were communicated by other recent studies as well (Hashem et al., 2014). Even though the importance of salt in obtaining the

\section{p-0.10}

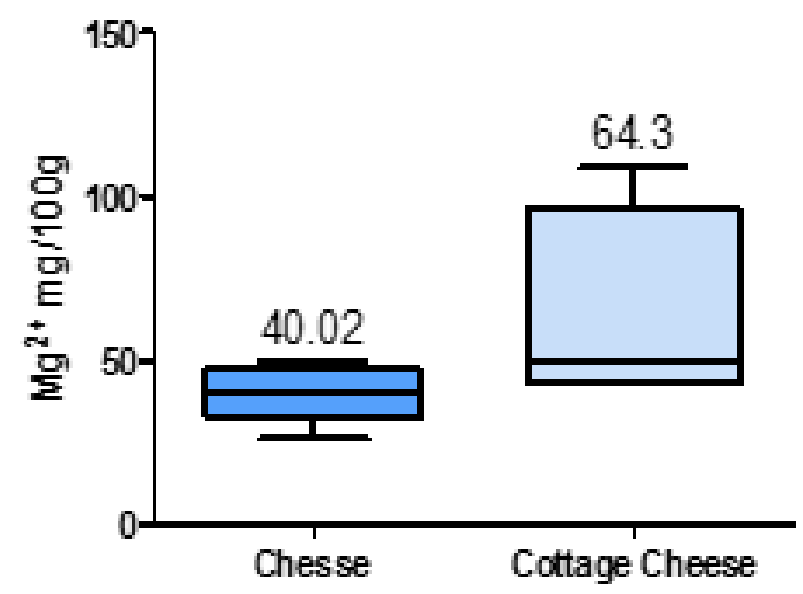

Fig.4. Mean values of magnesium in brine

texture and savor of the product has been already demonstrated (Pastorino et al., 2003; Shrestha et al., 2011), the tendency is to reduce the Na content or to replace it with other chlorine salts $(\mathrm{K}, \mathrm{Mg}$, Ca) (Johnson et al., 2009), but this has a negative influence upon savor and consumer acceptance (Grummer et al., 2013 ). Other researchers went further and quantified the effect on the micro flora in dairy when replacing totally or partially $\mathrm{NaCl}$ with $\mathrm{KCl}$, but the results have been insignificant (Wachowska, 2011; Ayyash et al., 2012.).

In consumer preferences through comparative tasting of salted and unsalted Cheese, 90.3\% (28 out of 31) preferred salted Cheese, the recorded differences have been statistically insignificant $(p=0.07)$. Consumer preferences in comparative tasting of salted Cheese with natural brine versus conventional brine, $69.2 \%$ (18 out of 26 ) have chosen natural brine, the differences being also statistically insignificant $(\mathrm{p}=0.16)$.

Our results indicate that salinity is an important sensorial attribute of food and implicitly dairy products, results that have been published by other researchers as well (McMahon et al., 2014). Even though adequate sodium content is vital for health and savor, its excess is link to the development of hypertension and associated pathologies (Karppanen et al., 2005). Taking this into account, WHO (2006) recommended a decrease in salt intake (under $5 \mathrm{~g}$ /day) as being one of the most important prevention methods for non-transmissible diseases (Hashem et al., 2014). It has been proven that a sodium rich diet during 
adolescents has negative implications on bone tissue development. Plus, the reduced magnesium and calcium retention caused by a sodium rich diet has negative implications on arterial pressure and cardiovascular disease (Palacios et al., 2013).

There are technological limitations in sodium use linked to the processing of food and consumer preferences that forces the food industry to discourage sodium reduction tendencies. Despite all this, mandating sodium reduction in some food categories would make the food industry to come up with a few creative solutions that would allow sodium reduction without compromising food safety and consumer preferences. There is no doubt that sodium reduction will be difficult, but there is also no doubt that reducing sodium levels is essential for the health of the population (Liem et al., 2011).

\section{CONCLUSION}

The data obtained showed significantly higher calcium content in Cheese $(p=0.008)$ and natural brine $(\mathrm{p}=0.009)$, and magnesium content in Telemea $(p=0.10)$. We have also found out that natural brine has a greater calcium $(188 \mathrm{mg} / 100 \mathrm{~g})$ and magnesium (14.2 mg/100g) contribution to Telemea. Consumer preferences are higher for salted Cheese (90.3\%) and for cheese salted through natural brine (69.2\%). In the end we conclude that, natural, mineral rich brine resulted to be mostly relevant and can increase the biological and sensory qualities of dairy products for a lower processing price.

\section{REFERENCES}

1. Asaria P, Chisholm D, Mathers C, Ezzati M, Beaglehole R (2007). Chronic disease prevention: health effects and financial costs of strategies to reduce salt intake and control tobacco use. Lancet 370:2044-53.

2. Ayyash MM, Sherkat F, Shah NP (2012). The effect of $\mathrm{NaCl}$ substitution with $\mathrm{KCl}$ on Akawi cheese: Chemical composition, proteolysis, angiotensin-converting enzymeinhibitory activity, probiotic survival, texture profile, and sensory properties. J. Dairy Sci 95:4747-4759.

3. France. World Health Organization (WHO) (2006). Reducing salt intake in populations. France World Health Organization, Paris.

4. Ganesan B, Brown K (2014). Informatic prediction of Cheddar cheese flavor pathway changes due to sodium substitution. FEMS Microbiol Lett 350:231-238.

5. Gaucheron F (2011). Milk and dairy products: a unique micronutrient combination. J Am Coll Nutr 30(5 Suppl 1):400S-9S.
6. Grummer J, Bobowski N, Karalus M, Vickers Z, Schoenfuss $\mathrm{T}$ (2013). Use of potassium chloride and flavor enhancers in low sodium Cheddar cheese. J Dairy Sci 96:1401-1418.

7. Hashem KM, He FJ, Jenner HK, MacGregor GA (2014). Cross-sectional survey of salt content in cheese: a major contributor to salt intake in the UK. BMJ Open 4(8).

8. Haug A, Høstmark AT, Harstad OM (2007). Bovine milk in human nutrition-a review. Lipids Health Dis 6:25.

9. He FJ, MacGregor GA (2010). Reducing population salt intake worldwide: from evidence to implementation. Prog Cardiovasc Dis 52:363-82.

10. He FJ, MacGregor GA (2011). Salt reduction lowers cardiovascular risk: meta-analysis of outcome trials. Lancet 378:380-2.

11. Johnson ME, Kapoor R, McMahon DJ, McCoy DR, Narasimmon RG (2009). Reduction of sodium and fat levels in natural and processed cheeses: Scientific and technological aspects. Compr Rev Food Sci Food Safety 8:252-268.

12. Karppanen H, Karppanen P, Mervaala E (2005). Why and how to implement sodium, potassium, calcium, and magnesium changes in food items and diets? Hum Hypertens 19:S10-S19.

13. Lawrence G, Salles C, Septier C, Busch J, Danguin T (2009). Odour-taste interactions: A way to enhance saltiness in low salt content solutions. Food Qual Prefer 20:241-248.

14. Liem DG, Miremadi F, Keast RSJ (2011). Reducing Sodium in Foods: The Effect on Flavor. Nutrients 3(6):694-711.

15. McMahon DJ, Oberg CJ, Drake MA, Farkye N, Moyes LV, Arnold MR, Ganesan B, Steele J, Broadbent JR (2014). Effect of sodium, potassium, magnesium, and calcium salt cations on $\mathrm{pH}$, proteolysis, organic acids, and microbial populations during storage of full-fat Cheddar cheese. Journal of Dairy Science 7:4780-4798.

16. Ognean L, Cernea LC, Fiţ N, Moldovan MM, Someşan R, Dragomir D (2012). The evaluation of the milk health and conformity level on a processing company chain with close and open circuit. Universitatea de Ştiinţe Agricole şi Medicină Veterinară Iaşi, Lucrări Ştiinţifice seria Medicină Veterinară 55:1-7.

17. Palacios C, Wigertz K, Braun M, Martin BR, McCabe GP, McCabe L, Pratt JH, Peacock M, Weaver CM (2013). Magnesium retention from metabolic-balance studies in female adolescents: impact of race, dietary salt, and calcium. Am J Clin Nutr 97(5):1014-1019.

18. Pastorino AJ, Hansen CL, McMahon DJ (2003). Effect of salt on structure-function relationships of cheese. J Dairy Sci 86:60-9.

19. Ross AC, Manson JE, Abrams SA et al (2011). Report on Dietary Reference Intakes for Calcium and Vitamin D from the Institute of Medicine: What Clinicians Need to Know. The Journal of Clinical Endocrinology and Metabolism 96(1):53-58.

20. Shrestha S, Grieder JA, McMahon DJ, Nummer BA (2011). Survival of Salmonella serovars introduced as a postaging contaminant during storage of low-salt cheddar cheese at 4, 10, and $21^{\circ} \mathrm{C}$. J Food Sci 76:M616-21. 
21. Someşan R, Ognean L, Tâncă S, Vlasiu A, Hărşan R (2013). Actualities regarding obtaining ecological dairy products. Bulletin of Univerity of Agricultural Sciences and Veterinary Medicine Cluj-Napoca. Veterinary Medicine 70(1).

22. United States of America. Institute of Medicine (IOM) (1997). Dietary Reference Intakes for calcium, phosphorus, magnesium, vitamin D, and fluoride. Institute of Medicine, Washington DC. http://www.iom.edu/ media/Files/Nutrition/DRIs/DRI_Elements.pdf.
23. Vahčić N, Hruškar M, Marković K, Banović M, Barić IC (2010). Essential minerals in milk and their daily intake through milk consumption. Mljekarstvo 60:77-85.

24. Wachowska M (2011). Microbiological changes in Edam-type cheese, brined in a mixture of sodium and potassium chloride during the ripening process. Milchwissenschaft 66:381-384. 